Parkchomenko N. M. Theoretical and practical background of legal regulation in the modern Ukraine

The major theoretical and practical problems of legal regulation of public relations in Ukraine at the current stage of development are determined. These problems are related to the need to address national and international political issues. Special reference is made to the number of existing factors that directly or indirectly affect content, pace, quality and efficiency of transformations in Ukraine. One of the principal factors is either the lack of scientific basis and scientific support or the disregard for the scientific soundness principle.

Consequently, the foundation of any transformations in the domain of state and law creation is a legal reform in general and constitutional reform in particular.

In this, continuous development of public relations requires the appropriate improvement not only separate elements of legal system but improvement of all the elements of social, economic and political systems. Furthermore, one of the key factors of reform's efficiency is consistency and also complexity of the reform's realization, harmonized legal regulation which will provide a stable link between them, creating an integrated whole thus creating awaited results.

First of all, the legislative process requires scientific support because quality assessment of current Ukrainian legislation, demonstrates the necessity of its continuous development. Also the important thing is taking into account all the factors of legislation's evolution which can be divided on economic, social, political, legal, ideologue, cultural and other factors.

It is pointed out that effective legal regulation and reforming of the government system including legal reform depends on their scientific basis. In this regard, among the current problems in the area of law at the current stage some of them should be allocated: understanding the substance and content of law, constitutional proceedings, non-execution of judgments and access to justice, ensuring human and civil rights and freedoms, ensuring national sovereignty and independence of Ukraine, improvement of judicial authority, the substance and content of civil society institutions, modernization of legal responsibility institution.

Thus, so far and for the entire period of Ukraine's independence, a number of extremely complex challenges to science were contributed for the purpose of methodological support of the state and law making processes.

The major theoretical and practical problems of legal regulation of public relations in Ukraine at the current stage of development are determined. It is important to note that lots of different factors directly or indirectly affect the content, pace, quality and efficiency of transformations in Ukraine. One of the principal factors is either the lack of scientific basis and scientific support or the disregard for the scientific soundness principle.

Key words: legal regulation, reform, realization of law, scientific basis, legal science.

DOI: 10.33.66.3/2524-017X-2019-10-77-82

УДК 340

T. С. Подорожна,

доктор юридичних наук, дочент доцент кафедри публічного права юридичного факультету Чернівецького національного університету імені Ю. Федьковича

О. В. Білоскурська,

кандадат юридичних наук, доцент кафедри публічного права юридичного факультету Чернівецьького національного університету імені Ю. Федьковича

\title{
ПРАВОВИЙ МОНІТОРИНГ ЯК ЗАСІБ ЯКОСТІ ТА ЕФЕКТИВНОСТІ ЧИННОГО ЗАКОНОДАВСТВА
}

Постановка проблеми. В Україні прийнято і діє безліч нормативних правових актів, що регулюють різноманітні сфери суспільного життя. Система законодавства постійно ускладнюється, відтак виникають внутрішньосистемні проблеми і відбуваються негативні якісні зміни (наприклад, поширення правових колізій). Дія великої кількості нормативних правових актів, систематичне внесення до них змін нерідко є суперечливими і конфліктними і не завжди ефективні для регулювання суспільних відносин. Тож актуальним є створення нормативної правової бази, яка відповідала б новим реаліям і тенденціям суспільного розвитку в Україні. Створенню ефективних юридичних норм сприяє використання певних юридичних технологій. У зв'язку із цим зростає значення правового 
моніторингу у вивченні динаміки чинного законодавства, його наукової обгрунтованості та модернізації. Проте в Україні ще не сформовано цілісної системи правового моніторингу, досі не врегульовано і питання правової експертизи нормативно-правових актів, відсутнє оцінювання раціональності їх прийняття та практичної реалізації. Ці проблеми істотно впливають і на якість чинного законодавства, i на їх соціальну ефективність. Тож знижується якість правового регулювання, зростають корупція та правовий нігілізм у суспільстві.

Ступінь наукової розробки проблеми. Питання теорії і практики правового моніторингу досліджують багато вчених, серед яких і зарубіжні, зокрема Ю. Арзамасов, І. Бачило, Д. Горохов, І. Жужгов, С. Миронова, Ю. Тихомиров, Д. Шнайдер, А. Щеглова. Серед вітчизняних учених-дослідників правового моніторингу варто згадати Ю. Градову, О. Зайчука, В. Косовича, Т. Подорожну, О. Копиленка, Л. Луць, Н. Пархоменко, Н. Оніщенко, О. Петришина, О. Скакун, І. Шутака, I. Онищука, Л. Легін та ін.

У формуванні доктринальних основ правового моніторингу (в широкому значенні, що не обмежується тією чи іншою стадією правового регулювання, видом правового акта тощо) особливу роль відіграли розробки Інституту держави і права імені В. М. Корецького НАН України (м. Київ), Львівської лабораторії прав людини і громадянина (м. Львів), Лабораторія академічних досліджень правового регулювання та юридичної техніки (м. Івано-Франківськ), Лабораторія людських прав (м. Чернівці), де представлені відповідні концепція, методика організації і проведення правового моніторингу. Відповідно до наукових розробок провідних вітчизняних учених, правовий моніторинг - це система інформаційних спостережень, за допомогою якої здійснюється аналіз й оцінка результатів правотворчої діяльності, якості й ефективності нормативних правових актів.

Питання правового моніторингу і на теоретичному, і на практичному рівнях також розробляють фахівці Інституту законодавства Верховної Ради України, серед основних завдань якого, відповідно до п. 2.5 Розпорядження Голови Верховної Ради України № 770 від 4 серпня 2003 р. «Про затвердження Положення про Інститут законодавства Верховної Ради України та його структури», $\epsilon$ організація моніторингу ефективності чинного законодавства України та прогнозування наслідків його застосування. Розроблені Інститутом законодавства та порівняльного правознавства методичні рекомендації з реалізації законів містять конкретні механізми правового моніторингу: 1) організаційні; 2) юридичні; 3) матеріально-фінансові; 4) соціально-психологічні; 5) способи оцінки ефективності норм права [3].

Виклад основного матеріалу. У науковій літературі правовий моніторинг розуміється як інструмент забезпечення ефективності нормативно-правових актів та практики їх застосування, що дозволяє побачити сучасний стан законодавства, дійсну картину його роботи, оцінити якість правового регулювання і з'ясувати причини гальмування досягнення поставлених правових цілей [3].

На законодавчому рівні правила проведення моніторингу закріплені в підзаконних нормативних правових актах, якими передбачено здійснення органами державної влади моніторингу правозастосування з метою вдосконалення правової системи держави. Тож важливим $є$ застосування подальшого моніторингу актів, за яким оцінюють їхній регулятивний вплив, щоб порівняти прогнозовані цілі і фактичні наслідки правового регулювання, а також оцінити якість самої процедури регулятивного впливу.

Проведення правового моніторингу дозволяє виявити різні дефекти правового регулювання (колізії, прогалини, невизначеність тощо), визначити потреби і напрями його вдосконалення й систематизації. 3 огляду на це, правовий моніторинг має велике значення в забезпеченні прозорості управлінської діяльності за допомогою інформування населення про стан вітчизняної правової системи, у встановленні зворотного зв'язку правотворчих органів і суспільства. Це сприяє підвищенню рівня правової культури і правосвідомості громадян та забезпечує більш повну реалізацію громадських правотворчих ініціатив (на сьогодні у Верховній Раді України вже зареєстровано Проект Закону про правотворчу народну ініціативу від 30.12.2013р.) [6]. Найбільшої популярності та результативності набувають громадські ініціативи, що ретранслюються за допомогою соціальних мереж, із залученням різноманітних інтернет-ресурсів.

Визнаючи очевидну значущість здійснюваного зараз моніторингу правозастосування та його регулювання, потрібно відзначити, що обмеження моніторингу галуззю правозастосування (якою навіть не вичерпується стадія правореалізації, що охоплює, крім цього, дотримання, виконання та використання юридичних норм), звуження його суб’єктного складу (з якого виклю- 
чені інші, крім виконавчої влади, правотворчі і передусім законотворчі органи, суди, фахова юридична спільнота, представники науки, бізнесу, громадянського суспільства тощо) не дозволяють повною мірою досягти його головної мети - підвищення ефективності правового регулювання, тоді як цьому покликані сприяти здійснювані на професійному рівні різними суб'єктами (насамперед правотворчими, а також судовими органами) постійне спостереження та аналіз прийняття і реалізації (у всіх формах) чинного законодавства.

У зв'язку із цим інтерес становить зарубіжний досвід правового регулювання моніторингу. У багатьох державах прийняті закони про нормативно-правові акти (про правові акти), які регулюють порядок розробки, експертизи, прийняття, офіційного опублікування, набуття чинності, зміни, припинення, тлумачення нормативних актів. У такі закони, як правило, вводяться норми про правовий моніторинг. Наприклад, Закон Республіки Казахстан від 6 квітня 2016 р. передбачає досить широке коло суб'єктів правового моніторингу, зараховуючи до них не тільки державні органи, а й недержавні і наукові організації, громадян, які залучаються до його проведення державними органами (пп. 2, 3 ст. 50). Крім того, цим Законом передбачено проведення Національною палатою підприємців Республіки Казахстан загального моніторингу нормативних правових актів (ст. 51).

У нещодавно прийнятому (17 липня 2018 р.) Законі Республіки Білорусь про нормативні правові акти також окреслено досить широке коло суб' єктів правового моніторингу, куди включені всі нормотворчі органи (посадові особи), до складу яких входять і органи місцевого самоврядування, а також інші уповноважені органи та організації. У цілях проведення правового моніторингу передбачені також публічні обговорення, вивчення пропозицій наукових організацій, громадських об'єднань, а також громадян з удосконалення законодавства і правозастосовної практики (ст. 75).

Правовий моніторинг дозволяє оцінити ефективність правового регулювання. Ефективність правових норм, права, правового регулювання $є$ предметом досліджень багатьох авторів. Відомі різні підходи до визначення ефективності у праві. Однак переважає погляд на ефективність в аспекті співвідношення цілей, для досягнення яких були прийняті відповідні норми права і $є$ результати ix реалізації. Методика здійснення моніторингу правозастосування має грунтуватися передусім на відповідній меті, для досягнення якої був прийнятий нормативний правовий акт, та на результатах його фактичної реалізації (тобто оцінка акта на предмет його ефективності). При цьому в деяких державах Свропи (Німеччина, Нідерланди та ін.) цей критерій є ключовим.

Варто також зазначити, що метою правового моніторингу є процедура оцінки якості фактичних наслідків правового регулювання, визначення досягнення заявлених цілей правового регулювання. Окрім нормативних правових актів, у ролі об'єкта моніторингу, а також його предмета і джерел інформації виступає судова практика. Однак судові органи не є повноважними суб'єктами моніторингу правозастосування в Україні, хоча, на нашу думку, саме вони здійснюють значний обсяг правозастосовної діяльності, вони частіше інших органів влади виявляють дефекти юридичних норм. У зв'язку із цим вищі судові органи (зокрема Верховний Суд та Конституційний Суд України) повинні бути наділені повноваженнями з проведення правового моніторингу на постійній основі.

Доцільно також залучати до правового моніторингу авторитетні наукові установи і вищі навчальні заклади. Наприклад, цим можуть займатися члени науково-консультативних рад, утворених при відповідних органах влади (наприклад, Науково-консультативної ради при Верховному Суді).

До системи правового моніторингу має входити прогностична компонента. Юридичне прогнозування як передбачення стану правової системи в майбутньому, розрахунок можливих наслідків і ризиків (юридичних, соціальних, економічних, фінансових, політичних, екологічних та ін.) прийняття, зміни та скасування юридичних норм багато в чому спирається на результати правового моніторингу [7]. Міжнародний досвід підтверджує ефективність техніки прогнозування в процесі правового моніторингу. Так, законотворення штату Мен (США) починається 3 того, що експерти комітетів і комісій вивчають тему, яку потрібно представити у вигляді доповіді. Складений звіт часто супроводжується прогнозуванням щодо проектів законів, які можуть забезпечити оптимальну модель врегулювання певного питання суспільних відносин. Звіти про дослідження опубліковуються і $є$ доступними на офіційному сайті.

На думку В. Андріюк, якщо моніторинг дозволяє виявити недоліки чинного правового регулювання, то прогноз пропонує альтернативні варіанти їх усунення [1]. При цьому потрібно мати на увазі, що результати моніторингу та прогнозування повинні враховуватися при плануванні (особливо перспективному) правотворчої діяльності. Наприклад, облік результатів правового моніто- 
рингу під час розробки планів підготовки проектів нормативних правових актів передбачений п. 3 ст. 38 Закону Республіки Білорусь про нормативні правові акти, п. 4 ст. 15 Закону Республіки Казахстан про правові акти. Згідно зі ст. 18 Закону від 20 липня 2009 р. № 241 про нормативні правові акти Киргизької Республіки, результати моніторингу й оцінки чинного законодавства враховуються при плануванні законопроектних робіт.

На жаль, доводиться констатувати, що правове регулювання в Україні позбавляє моніторинг його головної властивості - оперативності. Підсумки цієї діяльності публікуються раз на рік у доповіді Міністерства юстиції України, яка $є$ фактично єдиним офіційним документом, що представляє результати моніторингу у правовій сфері. Попри це, за своєю природою правовий моніторинг - це оперативний інструмент для створення законодавчих та інших нормативних правових актів, покликаний якомога швидше виявляти дефекти правового регулювання і негайно їх усувати. Він не може бути зведений до річного звіту, його результати повинні узагальнюватися частіше. Цьому має сприяти створення офіційної бази проектів нормативних правових актів, чинних нормативних правових актів та практики їх реалізації, що істотно полегшить процедуру правового моніторингу, а також єдиної інформаційної бази його результатів (де нормативний матеріал буде згруповано за сферами, стадіями правового регулювання, видам моніторингу, його суб'єктами, об'єктами тощо).

Також вважаємо, що в пояснювальних записках, насамперед до законопроектів, повинні відображатися дані правового моніторингу, якими слід обгрунтовувати необхідність прийняття законопроекту. Підтвердження цьому знаходимо у розглянутих вище зарубіжних законах про нормативні правові акти. Так, у ст. 25 Закону Киргизької Республіки про нормативні правові акти, що пред’являє вимоги до обгрунтування проекту нормативного правового акта (аналог пояснювальної записки в Україні) серед відомостей, які вона повинна містити, $\epsilon$ відомості про моніторинг і оцінку законодавства, що регулює певну сферу суспільних відносин. А Законом Республіки Білорусь про нормативні правові акти передбачено розробку концепції нормативного акта, яка, згідно з п. 2 ст. 43 цього закону, повинна містити й огляд результатів правового моніторингу. Така системна організація правотворчості та правозастосування сприятиме прийняттю Закону «Про нормативно-правові акти в Україні», що зумовлює необхідність закріплення основ правового моніторингу в цьому законі.

Наголосимо, що трансформація сфер правотворчості і правореалізації в умовах масштабної цифровізації можуть істотно позитивно вплинути на розвиток інституту правового моніторингу. Тому доцільно поділити процедури його проведення на кілька етапів. На попередньому етапі спостереження, аналіз та оцінку правотворчої діяльності, нормативних правових актів і практики їх реалізації, виявлення різних дефектів правового регулювання можна здійснювати, використовуючи штучний юридичний інтелект. На наступному етапі правового моніторингу уже людина, як уповноважений суб'єкт правового моніторингу, має аналізувати й оцінювати його об'єкти.

Перспективним вбачається також закріплення у правовій системі інституту громадського правового моніторингу, здійснюваного громадянами, інститутами громадянського суспільства, громадськими об’єднаннями тощо. Як слушно зауважує В. Косович, правовий моніторинг - це форма контролю суспільства за станом законодавства; він необхідний для забезпечення прав і свобод громадян, відкритості правотворчого процесу, зниження рівня суперечливості законодавства, забезпечення стабільності правової політики тощо [2]. Тому важливий крок у розвитку системи - залучення населення, громадянського суспільства до вирішення правових питань поряд з громадською правотворчою ініціативою і громадським обговоренням проектів нормативних правових актів. Для цього повинен бути створений інтернет-майданчик громадського правового моніторингу, результати якого законодавцю слід враховувати при розробці та вдосконаленні нормативних правових актів.

Висновки. Розвиток інституту правового моніторингу має здійснюватися в напрямках формалізації та уніфікації його основ у Законі «Про нормативно-правові акти в Україні»; розширення сфери правового моніторингу; вироблення загальних підходів до концепції подальшого розвитку моніторингових досліджень (наприклад, про необхідність виділення конституціоналізації чинного законодавства як напрямку подальшого аналізу, конституційного моніторингу та діагностики конституційних процесів [5]); проведення порівняльно-правових досліджень стану та векторів розвитку законодавства в умовах євроінтеграції; включення в суб'єктний склад правового моніторингу всіх гілок державної влади, органів місцевого самоврядування, громадянського суспільства, професійної юридичної спільноти, представників науки, незалежних експертів тощо; забезпечення 
оперативності правового моніторингу; надання обов'язкового характеру результатам правового моніторингу, зокрема шляхом обгрунтування необхідності прийняття законодавчих актів у сфері моніторингу; використання новітніх інформаційних технологій для створення офіційної бази проектів нормативних правових актів, а також чинного законодавства і практики їх реалізації, єдиної інформаційної бази результатів правового моніторингу, а також для застосування в процедурі правового моніторингу можливостей штучного юридичного інтелекту; впровадження суспільного (громадського) правового моніторингу та створення інтернет-порталу для його проведення.

\section{Список використаних джерел}

1. Андріюк В. В. Теоретико-методологічні основи юридичного прогнозування : автореф. дис. ... канд. юрид. наук: 12.00.01. Київ, 2007. 23 с.

2. Косович В. М. Удосконалення нормативно-правових актів України: техніко-технологічні аспекти: монографія. Львів: Львівський національний університет імені Івана Франка, 2015. 568 с.

3. Онищук I. I. Правовий моніторинг - інструмент забезпечення ефективного функціонування правової системи. Науково-інформаційний вісник. 2013. № 8. С. 72-80.

4. Онищук I. I. Правовий моніторинг: проблеми методології, теорії та практики: монографія. Івано-Франківськ; Дрогобич: Коло, 2017. 512 с.

5. Подорожна Т. С. Правовий порядок: теоретико-методологічні засади конституціоналізації: монографія. Київ: Юрінком Інтер, 2016. 536 c.

6. Проект Закону про правотворчу народну ініціативу від 30.12.2013 № 3847. URL: http://search.ligazakon.ua/1 doc2.nsf/link1/JG2YV00A.html (дата звернення: 20.03.2019).

7. Радченко В. И. Прогнозирование развития законодательства и эффективности его применения в ходе проведения правового мониторинга. Правовой мониторинг: актуальные проблемы теории и практики / под ред. Н. Н. Черногора. Москва: Изд-во Междунар. юрид. ин-та, 2010. С. 213-232.

\section{Подорожна Т. С., Білоскурська О. В. Правовий моніторинг як засіб якості та ефективності чинного} законодавства

У статті досліджено поняття правового моніторингу з погляду якості та ефективності правового регулювання. Зауважено, що значення правового моніторингу зростає у вивченні динаміки чинного законодавства, його наукової обгрунтованості та модернізації. Проте в Україні ще не сформовано цілісної системи правового моніторингу, не врегульовано досі й питання правової експертизи нормативно-правових актів, відсутнє оцінювання раціональності їх прийняття та практичної реалізації. Наголошено, що ці проблеми істотно впливають і на якість чинного законодавства, і на їх соціальну ефективність. Відтак знижується якість правового регулювання, зростає корупція та правовий нігілізм у суспільстві.

Зроблено висновок, що розвиток інституту правового моніторингу має здійснюватися в напрямках формалізації та уніфікації його основ у Законі «Про нормативно-правові акти в Україні»; вироблення загальних підходів до концепції подальшого розвитку моніторингових досліджень (наприклад, про необхідність виділення конституціоналізації чинного законодавства як напрямку подальшого аналізу, конституційного моніторингу та діагностики конституційних процесів); введення до суб'єктного складу правового моніторингу всіх гілок державної влади, органів місцевого самоврядування, громадянського суспільства, професійної юридичної спільноти, представників науки, незалежних експертів тощо; забезпечення оперативності правового моніторингу; надання обов'язкового характеру результатам правового моніторингу; використання новітніх інформаційних технологій для створення офіційної бази проектів нормативних правових актів, а також чинного законодавства і практики їх реалізації, впровадження суспільного (громадського) правового моніторингу та створення інтернет-порталу для його проведення.

Ключові слова: правовий моніторинг, правова експертиза, ефективність правового регулювання, якість законодавства, конституціоналізація законодавства, громадянське суспільство, громадський правовий моніторинг.

Podorozhna T. S., Beloskurska O. V. Legal monitoring as a quality assurance and effectiveness of any legislation

This article clarifies one of the important legal questions regarding the concept of legal monitoring, which is viewed from the perspective of the quality and effectiveness of legal regulation. Having teased out some of the challenges, the author calls for the axiological potential of legal monitoring. Despite the significant implications of the pushback, the level of investigation of the outlined phenomenon has increased significantly. This has been confirmed by the dynamics of current legislation, its scientific validity and modernization. Nevertheless, Ukraine has not yet established an integral system of legal monitoring. As shown in the article, legal expertise of regulatory acts remains unresolved, and there is no thorough assessment of the rationality of their adoption and further practical implementation. It is emphasized 
that these problems have a significant impact on the quality of current national legislation, as well as on their social effectiveness. Consequently, the quality of legal regulation is steadily decreasing, while the corruption and legal nihilism continue to grow in society.

This article uses empirical data obtained from domestic legislation to make some preliminary conclusions about the challenges peculiar for the institute of legal monitoring. The author argues this should be carried out in the areas of formalization and unification in the Law «On regulatory legal acts in Ukraine»; development of common approaches to the concept of further development of monitoring examinations (for example, regarding the need to single out the constitutionalization of existing legislation as a direction for the further analysis, constitutional monitoring and diagnostics of the certain constitutional processes); the inclusion in the subject structure of legal monitoring of all branches of governmental authorities, local governments, civil society, professional legal community, representatives of national jurisprudence, independent experts, etc.; ensuring prompt legal monitoring; provision of mandatory results to legal monitoring; the use of the latest information and communications technology necessary to create the official base of projects of regulatory legal acts, as well as the current legislation and practice of their implementation, the introduction of public (civil) legal monitoring and the creation of an Web-portal for its practical realization.

Key words: legal monitoring, legal expertise, effectiveness of legal regulation, quality of legislation, constitutionalization of legislation, civil society, public legal monitoring.

DOI: 10.33.66.3/2524-017X-2019-10-82-87

УДК 340.115

Ілля Дмитрович Шутак, професор кафедри теорії та історії держави і права Університету Короля Данила, доктор юридичних наук, професор, заслужений діяч науки і техніки Украйни

\section{ПРАВОВИЙ МОНТТОРИНГ НОРМОТВОРЕННЯ, РЕАЛІЗАЦІЇ ТА ТЛУМАЧЕННЯ НОРМ ПРАВА В КОНТЕКСТІ ПРИНЦИПУ ВЕРХОВЕНСТВА ПРАВА}

Постановка проблеми. Становлення нової правової системи в Україні відбувається досить складно, з розбіжностями. Негативною тенденцією в розвитку вітчизняного законодавства $\epsilon$ недостатня юридично-технічна опрацьованість актів законодавства, неналежне наукове обгрунтування правотворчих рішень, відсутність науково обгрунтованої технології законодавчого процесу.

Запровадження кожного законодавчого акта викликає у виконавців доволі різні почуття: від позитивного ставлення до необхідності роз'яснення деяких статей та пояснень щодо механізму практичного застосування окремих положень до негативного сприйняття його в цілому.

Нереалізованим досі залишається конституційне забезпечення пріоритетності законодавства. Головними причинами невиконання законів є: правовий нігілізм; помилкове праворозуміння; юридичні колізії між нормами права та нормативно-правовими актами (далі - НПА). Без дієвого механізму моніторингу ефективності НПА неможливо вчасно та якісно вирішити проблемні ситуації. Правовий моніторинг сприятиме досягненню ефективності чинного законодавства, відповідності його змісту сучасним вимогам розвитку держави та їі інститутів.

Аналіз останніх досліджень та пуб̆лікацій. Проблематику методології та методики оцінювання ефективності норм права у своїх наукових працях розкрили М. Шаргородський [4], А. Пашков та Л. Явич [5].

Загальнотеоретичні питання теорії держави та права, зокрема принципу верховенства права висвітлили М. Цвік, О. Петришин та Л. Авраменко [2].

Актуальні питання теорії та практики правового моніторингу досліджують зарубіжні вчені, зокрема М. Нарбінова [8], Ю. Тіхоміров [6], М. Турецький [7], Н. Черногора [3] та ін.

Однією з сучасних вітчизняних розробок, присвячених комплексному дослідженню правового моніторингу, є монографія I. I. Онищука. Автор розкрив організаційну, управлінську, інсти- 